Graduate Institute of International and Development Studies

International Economics Department

Working Paper Series

Working Paper No. HEIDWP18-2015

\title{
Billions on the Sidewalk \\ Improving Savings by Reducing Investment Mistakes
}

Ugo Panizza

The Graduate Institute, Geneva

and CEPR

Chemin Eugène-Rigot 2

P.O. Box 136

CH - 1211 Geneva 21

Switzerland

(C) The Authors. All rights reserved. Working Papers describe research in progress by the author(s) and are published to elicit comments and to further debate. No part of this paper may be reproduced without the permission of the authors. 


\title{
Billions on the Sidewalk Improving Savings by Reducing Investment Mistakes
}

\author{
Ugo Panizza \\ The Graduate Institute, Geneva \\ and $\mathrm{CEPR}^{*}$
}

September 2015

\begin{abstract}
This paper contributes the on-going debate on income inequality in advanced economies with a proposal aimed at reducing costly investment mistakes that are prevalent among middle-class households. The paper starts by describing how households should invest, compares it with what we know about how households do invest, and highlights discrepancies between the two (investment mistakes). After evaluating the costs of investment mistakes, the paper suggests that they could be reduced by accommodating cognitive biases through a simple process of financial education and appropriate default options. The policy described in this paper is immediately actionable at basically no cost and can have a large effect on the welfare of middle-class households in advanced economies.
\end{abstract}

Keywords: Household finance, Inequality, Growth

JEL Codes: D14, D18, F36, G18

*Pictet Chair in Finance and Development. Email: Ugo.Panizza@graduateinstitute.ch. Paper prepared for Finding Sustainable and Scalable Solutions to Foster Inclusive Growth, a Symposium on Inclusive Growth and Development to be held at Harvard University on October 1-2, 2015 and coordinated by the Center for International Development at Harvard and the World Economic Forum's Global Agenda Meta-Council on Inclusive Growth. I would like to thank the selection committee for inviting me to write this paper, Jonathan Ostry, Veronica Frisancho, Sonia Boffa, and Ezzat Jaroudi for helpful comments and suggestions, and Melissa Donohoe for oustanding research assistance. Sections 2-4 of this paper draw heavily on Campbell (2006) and Guiso and Sodini (2013). The usual caveats apply. 


\section{Introduction}

Recent research in household finance shows that investment mistakes have large costs. This paper describes a proposal aimed at reducing these mistakes by improving the way in which households invest their savings. Therefore, the paper contributes to the field of household financial engineering by building on Campbell's (2006) idea of putting in place policies that "suggest appropriate default investment options, or encourage public provision of simple financial products."

I start by describing what we know about how households should invest (what Campbell 2006 calls normative household finance), compare this with what we know about how households do invest (positive household finance), and highlight discrepancies between the two (investment mistakes). I show that these investment mistakes are costly. In advanced economies, they are likely to add up to more than 1 percent of GDP, with an estimated total cost of $\$ 450$ billion. ${ }^{1}$

Next, I suggest that investment mistakes could be reduced with a process of financial education and modified versions of already available ETF-like instruments that track a world equity index. To increase its salience and transform the process into a learning by investing activity, I suggest that financial education should be delivered when a household decides to invest and that it should provide concrete advice based on simple rules of thumb.

The paper contributes to the on-going debate on the causes and consequences of increasing income and wealth inequality in advanced economies. Empirical evidence suggests that initial wealth inequality is amplified by differences in investment strategies across income groups. It is also possible that investment mistakes of naive (and often poorer) households generate cross-subsidies which end up benefitting more sophisticated (and richer) investors (Gabaix and Liabson 2006). Policies that attenuate these differences in investors' beha-

\footnotetext{
${ }^{1}$ Sections 2-4 show that in the US, fees related to active investing are close to $\$ 110$ billion. This figure does not include the costs of non-participation and underdiversification. In Sweden (the only country for which figures are available), costs of non-participation and underdiversification add up to one percent of GDP. Figures for Sweden and the US are likely to be a lower bound for investment mistakes in other advanced economies because US and Swedish households tend to be more financially sophisticated than households in other countries.
} 
vior can therefore play a role in reducing income and wealth inequality and can spread the returns of world growth more evenly.

At the macro level, the proposal described in this paper can stimulate growth by reducing the cost of equity capital, promoting risk-sharing, and creating demand for long-term financial products that are well-suited to finance infrastructure projects.

I focus on the allocation of a given amount of savings. Therefore, I do not discuss the equally important issue of how to increase savings. ${ }^{2}$ Moreover, the proposal described in this paper requires a moderate savings capacity and is targeted to households who already own some basic formal financial instruments, such as a checking account. Hence, the paper will not cover issues that are specific to the poor in low-income countries where nearly 60 percent of the population does not have a bank account (Karlan et al. 2014). The ideas discussed in this paper are instead relevant for the middle-class in emerging market countries and most segments of the population in advanced economies.

\section{How should households invest?}

Given the need to plan over a lifetime, developing an optimal strategy for household investment is a difficult task. While standard investment models assume that all wealth is both liquid and tradable (Merton 1969, 1971), in most households the largest components of wealth are human capital and housing. The latter is tradable but lumpy and illiquid and the former is neither tradable nor pledgeable as collateral. As a consequence, households, especially young households, are often credit and liquidity constrained.

Differences in risk aversion are a key element in determining optimal investment behavior. If all investors have access to the same set of financial assets, investment choices should be fully driven by the degree of risk aversion. If risk aversion does not depend on wealth (a constant Arrow-Pratt degree of risk aversion, or CRRA, in technical jargon) all

\footnotetext{
${ }^{2}$ In fact, my proposal has an ambiguous effect on savings because the income and substitution effects are likely to go in different directions. Benartzi and Thaler (2013) provide a recent discussion on how to use results from behavioral economics to increase retirement savings in the US. Karlan et al. (2014) survey the literature on low income countries.
} 
investors, rich and poor, should hold the same share of risky assets in their portfolio. If, instead, investors' preferences display decreasing relative risk aversion (DRRA), the optimal share of risky assets increases with wealth. ${ }^{3}$

Because of uncertainty about optimal investors' behavior, Campbell (2006) states that: "Until some consensus is reached, normative household finance should emphasize results that are robust to alternative specification of household utility."

There is at least one result that appears to be robust to a large class of models: all investors should participate in all risky asset markets by investing in a portfolio which includes all securities with weights which are proportional to the market capitalization of each security (the market portfolio).

With constant relative risk aversion, the share of financial assets invested in the market portfolio should be the same for all households. With decreasing risk aversion the share of assets invested in the market portfolio should be increasing with wealth. However, the premium associated with holding risky assets is so large (Mehra and Prescott 1985) that all households should hold a positive fraction of their financial wealth in the risky market portfolio.

\section{How do households invest?}

Data on actual investment behavior are hard to obtain because household finance surveys are costly to implement and individual investors, especially the wealthy ones, do not like to disclose information about their financial assets (in the US, non-response ratios among the wealthiest groups are above 50 percent, Campbell, 2006). Such surveys exist for most advanced economies but, in order to obtain reasonable response ratios, they do not in-

\footnotetext{
${ }^{3}$ Decreasing relative risk aversion can be justified with utility functions that have non-standard bequest motives, habit formation, or consumption commitments. Research shows that there is substantial heterogeneity in risk aversion across households and that risk aversion is negatively correlated with wealth and IQ and positively correlated with the volatility of labor income and the presence of credit constraints (Guiso and Sodini 2013 review the literature). These findings suggest that the optimal share of risky assets should be higher for wealthier households and for households with more stable jobs and access to well-working financial markets. There is also evidence that women are more risk averse than men, that risk aversion increases with age and with exposure to risk in the past, and that there is a genetic component of risk-taking.
} 
clude specific questions about asset composition. These surveys can be used to estimate household participation in different asset classes but cannot be used to estimate the cost of investment mistakes. The only comprehensive and detailed data sources of household finance are administrative data for countries that have a comprehensive wealth tax.

\subsection{Investment mistake I: Non-participation}

Theory suggests that all households should participate in all financial markets and thus hold risky financial assets. However, only a small share of households participates in such markets.

Table 1 reports data for direct and indirect (through mutual and pension funds) stock ownership. In most countries less than 50 percent of households own stocks (the exception is Sweden where 66 percent of households hold stocks). There are also large cross-country differences. The share of households who own stocks is below 10 percent in Austria, Greece, Italy, and Spain, and less than one-third of households hold stocks in France, Germany, Switzerland, and the UK.

The table shows that the share of households who own stocks increases with wealth (a finding consistent with the presence of decreasing relative risk-aversion). However, even when we look at relatively wealthy households we find that stock ownership is low. At the top 25 percent of the wealth distribution, we find 9 countries (out of 12) where less than two-thirds of households hold stocks. Even at the top 5 percent of the wealth distribution

stock ownership is far from universal, with 8 countries where less than three-quarters of households own stocks.

Three things are worth noting:

1. Even in the country with the highest rate of participation in the stock market, onethird of households do not hold any stocks.

2. While we do not have data for developing and emerging market countries, Table 1 suggests that there is a positive correlation between income per capita and particip- 
Table 1: Percentage of households with direct and indirect (via mutual funds and pension funds) ownership of stocks

\begin{tabular}{lcccccc}
\hline \hline & & \multicolumn{4}{c}{ Quartiles } & Top 5\% \\
\cline { 3 - 6 } & & 1st & 2nd & 3rd & 4th & \\
\hline Austria & 8.8 & 0 & 1.9 & 8.1 & 25.5 & 33.8 \\
Denmark & 37 & 6.6 & 30.8 & 44.8 & 65.7 & 75.4 \\
France & 26.2 & 1.1 & 17.6 & 29.9 & 57.6 & 67.3 \\
Germany & 22.9 & 1.5 & 11.8 & 28.7 & 51.4 & 61.2 \\
Greece & 6.3 & 0 & 0.7 & 4 & 22.2 & 32.9 \\
Italy & 8.2 & 0 & 0.8 & 5.2 & 27.5 & 64.8 \\
Netherlands & 24.1 & 1.7 & 11 & 31.3 & 52.8 & 72 \\
Spain & 5.4 & 0 & 1.1 & 3 & 19.1 & 24.6 \\
Sweden & 66.2 & 25.8 & 63.4 & 82.7 & 92.9 & 95.8 \\
Switzerland & 31.4 & 2.8 & 20 & 38.2 & 63.7 & 65.8 \\
U.K. & 31.5 & 4.9 & 11.9 & 37.8 & 71.1 & 83.9 \\
U.S. & 48.9 & 4.4 & 38.3 & 66 & 86.7 & 93.7 \\
\hline \hline
\end{tabular}

Source: Guiso and Sodini (2013)

ation in risky financial assets. It is thus likely that data for developing and emerging market countries would reveal even lower participation rates.

3. Sweden is the only country for which there are precise estimates of the cost of investment mistakes. Given that Swedish households appear to be more financially sophisticated than households in other advanced economies (or, at least, they have the highest rate of participation in risky assets), it is reasonable to assume that Swedish data provide a lower bound for the cost of investment mistakes in other countries.

Table 2 looks at a broader measure of risky asset ownership (stocks, mutual funds, and bonds). Again, we find low average participation (the overall average for the eurozone is 20 percent). As before, the participation rate increases with wealth but remains low even for relatively wealthy households. The eurozone average goes from 3 percent for the bottom quintile to 55 percent for the top 5 percent of the wealth distribution. As before, there are large differences across countries. Average participation rates go from 4 percent in Greece and Slovakia to 39 percent in Finland (Table 2 only includes countries that are part of the eurozone and therefore does not have data for Sweden). Such large heterogeneity also 
Table 2: Percentage of households owning risky financial assets (mutual funds, bonds, and stocks)

\begin{tabular}{lccccccc}
\hline \hline & Overall & \multicolumn{5}{c}{ Quintiles } & Top 5\% \\
\cline { 3 - 7 } & & $1^{\text {st }}$ & $2^{\text {nd }}$ & $3^{\text {rd }}$ & $4^{\text {th }}$ & $5^{\text {th }}$ & \\
\hline Euro area & 20.2 & 3.1 & 13.0 & 17.0 & 23.7 & 44.2 & 55.0 \\
Austria & 14.6 & 2.4 & 4.4 & 13.8 & 18.5 & 33.8 & 38.9 \\
Belgium & 30.7 & 4.8 & 18.6 & 25.7 & 38.8 & 65.7 & 72.8 \\
Germany & 23.0 & 3.5 & 9.0 & 27.1 & 28.0 & 47.5 & 55.7 \\
Spain & 14.0 & 1.8 & 5.1 & 9.3 & 17.8 & 36.2 & 48.6 \\
Finland & 38.7 & 14.6 & 29.7 & 36.1 & 45.7 & 67.4 & 81.7 \\
France & 21.7 & 3.0 & 10.9 & 19.1 & 27.9 & 47.5 & 63.8 \\
Greece & 4.0 & 0.4 & 1.1 & 1.6 & 3.9 & 12.8 & 22.8 \\
Italy & 19.8 & 1.0 & 11.1 & 14.4 & 28.6 & 44.0 & 53.6 \\
Netherlands & 23.9 & 7.8 & 12.4 & 23.9 & 29.7 & 45.8 & 60.3 \\
Portugal & 6.5 & 0.9 & 1.4 & 4.0 & 6.5 & 19.9 & 37.6 \\
Slovenia & 20.3 & 9.8 & 11.6 & 15.3 & 27.4 & 37.9 & 55.0 \\
Slovakia & 4.1 & 1.6 & 2.2 & 3.9 & 5.2 & 7.6 & 11.8 \\
\hline \hline
\end{tabular}

Source: Eurosystem Household Finance and Consumption Survey (HFCS) from Arrondel et al. (2014)

applies if we look at wealthy households (the top 5 percent), where participation rates range between 12 (Slovakia) and 82 percent (Finland).

Data on direct stock ownership show patterns that are similar to those of Tables 1 and 2. In the Eurozone, only 10 percent of households own stocks, with stock ownership going from 2 percent in the bottom quintile of the wealth distribution to 30 percent in the top decile. In 15 of the 16 countries of Table 3, less than 5 percent of the bottom quintile own stocks (quartile in the case of Sweden, Switzerland, the UK and US; note that data for these countries come from different sources). Even if we focus on the top decile (or top 5 percent), we still find that in 18 of the 19 countries listed in Table 3 at least 30 percent of households do not hold any stocks.

Summing up, while theory suggests that all households should own at least some risky financial asset, a large proportion of households does not hold any risky financial asset. This is the first investment mistake. 
Table 3: Percentage of households with direct ownership of stocks

\begin{tabular}{|c|c|c|c|c|c|c|c|}
\hline & \multirow[t]{2}{*}{ Overall } & \multicolumn{4}{|c|}{ Quintiles } & \multicolumn{2}{|c|}{ Deciles } \\
\hline & & $1^{s t}$ & $2^{\text {nd }}$ & $3^{\text {rd }}$ & $4^{t h}$ & $9^{t h}$ & $10^{t h}$ \\
\hline Euro area & 10.1 & 2.2 & 4.2 & 7.2 & 12.3 & 18.8 & 30.0 \\
\hline Austria & 5.3 & 1.6 & 2.6 & 4.4 & 6.8 & 10.1 & 12.3 \\
\hline Belgium & 14.7 & 3.0 & 9.4 & 14.0 & 19.1 & 26.6 & 29.9 \\
\hline Finland & 22.2 & 8.2 & 15.5 & 20.4 & 22.9 & 32.8 & 55.0 \\
\hline France & 14.7 & 2.7 & 6.4 & 11.0 & 17.0 & 29.6 & 42.9 \\
\hline Germany & 10.6 & 2.4 & 4.2 & 8.2 & 12.9 & 18.6 & 32.2 \\
\hline Greece & 2.7 & 0.5 & 0.4 & 2.0 & 3.1 & 8.2 & 7.0 \\
\hline Italy & 4.6 & 0.3 & 0.8 & 3.2 & 5.2 & 9.2 & 17.5 \\
\hline Netherlands & 10.4 & 5.3 & 8.6 & 9.7 & 12.6 & 13.8 & 18.4 \\
\hline Portugal & 4.4 & 0.8 & 0.7 & 1.8 & 3.8 & 6.7 & 23.0 \\
\hline Slovakia & 0.8 & 0.8 & 0.5 & 0.6 & 0.8 & 2.0 & 0.3 \\
\hline Slovenia & 10.0 & 6.7 & 6.6 & 10.0 & 10.1 & 11.8 & 21.7 \\
\hline \multirow[t]{3}{*}{ Spain } & 10.4 & 3.7 & 6.2 & 6.5 & 9.8 & 17.1 & 34.8 \\
\hline & \multirow[t]{2}{*}{ Overall } & \multicolumn{4}{|c|}{ Quartiles } & \multirow{2}{*}{\multicolumn{2}{|c|}{ Top 5\% }} \\
\hline & & \multicolumn{4}{|c|}{$2^{\text {nd }} \quad 3^{\text {rd }}$} & & \\
\hline$\overline{\mathrm{USA}}$ & 19.2 & 1.4 & 6.9 & 20.6 & 47.9 & \multicolumn{2}{|c|}{70.1} \\
\hline UK & 21.6 & 0 & 4.4 & 28.3 & 53.6 & \multicolumn{2}{|c|}{67.9} \\
\hline Sweden & 40.8 & 12.9 & 30.7 & 46.9 & 72.8 & \multicolumn{2}{|c|}{80.6} \\
\hline Switzerland & 24.9 & 2.8 & 12.2 & 30.3 & 54.2 & \multicolumn{2}{|c|}{63.2} \\
\hline
\end{tabular}

\subsection{Investment mistake II: Underdiversification}

The previous section highlighted investment mistakes linked to non-participation. Here we focus on the investment mistakes of households who hold risky financial assets.

Guiso and Sodini (2013) show that investors often underdiversify and take uncompensated risk. Their survey identifies the following investment mistakes linked to underdiversification:

1. Excessive concentration. Households who directly own individual equities hold a very small number of stocks (in the US, the median number is three) and US-based investors often have large holdings in the stock of their employers.

2. Home bias at the national and local level. Households do not hold enough foreign stocks and are more likely to hold stocks of companies that are geographically close 
to the household's place of residence. ${ }^{4}$

3. Excessive trading. Many investors engage in intensive stock trading and are often too quick in realizing gains by selling winners while holding onto losers for too long in order to avoid realizing losses (the disposition effect, more on this below).

These findings seem to contradict best practices which suggest that households should buy and hold an internationally diversified portfolio of risky financial assets and only trade to rebalance the portfolio according to their risk preferences and age profile.

\subsection{Investment mistake III: Sub-optimal financial advice and active in- vesting}

Surveys in the US and European Union show that between 70 and 80 percent of retail investors seek financial advice before making investment decisions (Chater et al. 2010, Hung et al. 2008). Is this a good thing?

On the one hand, economies of scale give financial experts an advantage in collecting information about investment opportunities and financial advisors can help households in avoiding the most common behavioral biases (such as excessive trading and the disposition effect). On the other hand, fees (either implicit or explicit) may lead to lower returns. Additionally, it is not clear whether the incentives of financial advisors are aligned with those of retail investors (Inderst and Ottaviani 2009, 2012a,b).

Hackethal et al. (2012) test for these tradeoffs by using data from a large German brokerage firm. While simple comparisons show that the portfolios of retail investors who use financial advisors outperform the portfolios of investors who do not use advisors, Hackethal et al. (2012) show that these two types of investors are different from each other. After controlling for these differences and allowing for endogeneity in the decision of whether to use the services of a financial advisor, they find that the use of financial advisors leads to lower returns and higher portfolio risk.

\footnotetext{
${ }^{4}$ These two factors are correlated. The local bias is higher for investors who do not hold foreign stocks.
} 
Fecht et al. (2013) find evidence of conflict of interest in the advice provided by banks to their clients and suggest that the Chinese wall between client advisors and proprietary trading desks is far from watertight. Specifically, they use security-by-security data on the stock holdings of all German banks, and stock holdings of the retail clients of these banks, to show that:

1. When banks want to remove stocks from their proprietary trading books they push these stocks to retail customers without proper disclosure. This effect is larger for illiquid stocks, supporting the idea that banks sell stocks to their clients in order to avoid the market impact of these sales.

2. The stocks that flow from banks' proprietary trading desks to retail clients underperform both other stocks in the bank portfolio and other stocks in the clients' portfolio.

3. The performance of the stock portfolio of retail investors who have accounts in banks that do not have a proprietary trading desk is higher than the performance of the portfolio of investors who are clients of banks with a proprietary trading desk.

Bergstresser et al. (2009) assess the costs and benefits of brokers in the US mutual fund industry. They estimate that in 2004 distribution fees captured by US brokers added up to $\$ 10$ billion and find that, on a risk-adjusted basis, mutual funds sold by brokers underperform funds sold through direct channels, even before subtracting distribution fees. The same authors also find that funds sold by brokers do not have lower non-distribution expenses and that using a broker does not improve market timing or attenuate investment biases in terms of return-chasing. Finally, they find that brokers push funds with higher distribution fees. ${ }^{5}$ This latter result is in line with the hypothesis that brokers do not always act in their clients' best interest.

\footnotetext{
${ }^{5}$ In the US, nearly 80 percent of mutual fund assets are invested in high-fee actively managed funds and 90 percent of these funds have undeperformed the market over 2003-2012 (Ferri and Benke 2013). This finding proves that while it is hard to beat the market, it is easy to waste money trying to do it. Evidence of wide dispersion in the fees charged by funds that provide the same service (tracking the S\&P500 index, see Hortaçsu and Syverson 2004 and Choi et al. 2010) suggests that there are substantial market failures and information gaps in the market for mutual funds.
} 


\section{The costs of investment mistakes}

Calvet et al. (2007) use detailed data from Swedish tax reports to evaluate the costs of the first two investment mistakes described above. They compare the return and volatility of the actual portfolios of Swedish households with a benchmark model based on a globally diversified equity portfolio (specifically, they use the MSCI All Country World Index). Their analysis yields four main results.

1. The median Swedish household is a good investor. While there is limited diversification in individual stocks, many participating households hold well-diversified mutual funds which allow them to achieve Sharpe ratios (the mean excess return over cash divided by return volatility) that are not far from the maximum achievable by investing in a global equity index. Calvet et al. (2007) estimate that the median Swedish household who holds risky assets loses about $\$ 120$ per year with respect to holding a currencyhedged world index. ${ }^{6}$ This loss is equivalent to approximately 1 percent of median financial wealth and 3 percent of median financial wealth invested in risky assets.

2. There is substantial cross-sectional heterogeneity in the efficiency of investment decisions of Swedish households who hold risky assets. A minority of severely undiversified households face large losses compared to investing in the world index. Households at the 95 th percentile of the distribution lose more than $\$ 2,200$ per year with respect to the world index.

3. Financial sophistication is a mixed blessing. Wealthier and more educated households hold more efficient portfolios of risky assets (i.e., portfolios with higher Sharpe ratios) but overinvest in risky assets. While efficient portfolios reduce investment losses of these households, excessive risk-taking increases losses. Since the latter effect dominates the former, the average loss from underdiversification is larger for sophisticated households.

\footnotetext{
${ }^{6}$ The risky portfolio of a participating household has a median value of $\$ 4,300$ and earns a risk premium over cash of $\$ 260$ instead of the $\$ 380$ it could earn by choosing an efficient portfolio with the same volatility.
} 
4. Out is a second-best strategy for the unsophisticated. Households with low wealth and education are poor investors. All other things equal, these households would face large losses from underdiversification. However, all other things are not equal. These households either do not participate or hold very small shares of risk assets. Nonparticipation, therefore, reduces losses for unsophisticated households which would be poor investors if they decided to participate. The naive non-participation cost (calculated by assuming that if a non-participant were to enter the market she would invest efficiently) is 4.3 percent of financial wealth. However, non-participants are unlikely to adopt an efficient investment strategy. When Calvet et al. (2007) assume that non-participants who enter the market for risky assets adopt the same investment strategy of participants with similar characteristics in terms of wealth education and other demographic variables, they find that the cost of non-participation drops to about 2.3 percent of financial wealth.

Table 4 summarizes the costs of underdiversification and non-participation for Swedish households. We can use these figures to ask the following question: what would the total gain for Swedish households of completely eliminating investment mistakes (i.e., of going from the current situation to a situation in which all households participate in risky financial markets and invest efficiently) be?

Table 4: Cost of investment mistakes for Swedish households

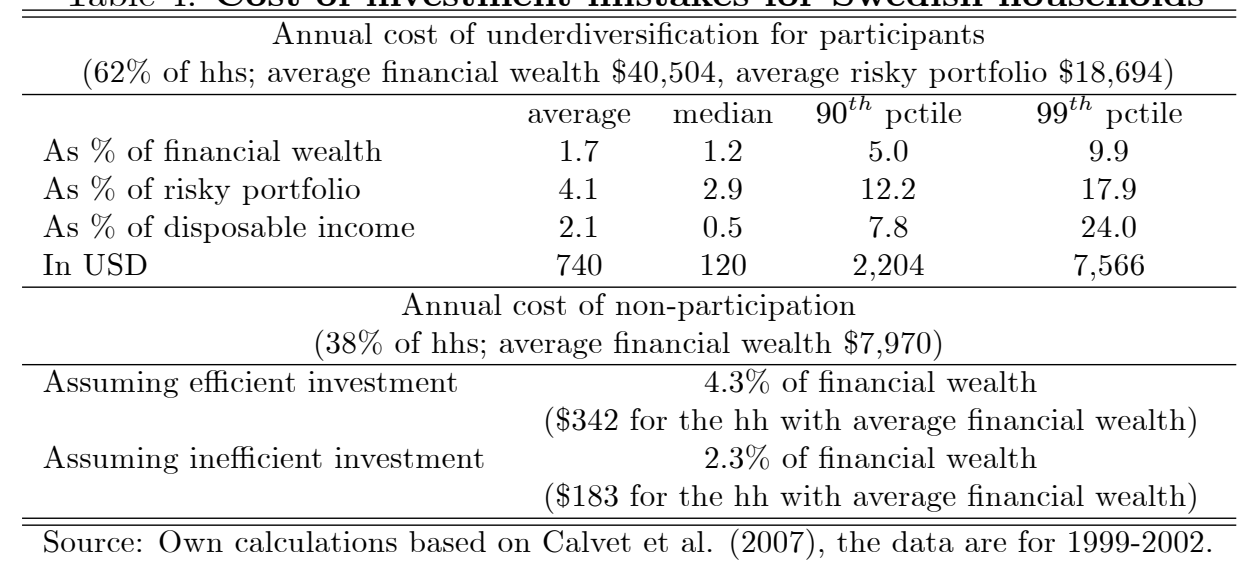


Underdiversification of households who participate in risky financial markets leads to an average return loss of $\$ 740 .^{7}$ By applying this figure to the 3 million households (62 percent of total) that participate in risky financial asset markets, we obtain $\$ 2.2$ billion. The average loss of non-participation is instead $\$ 342$ which multiplied by the 1.8 million households that do not participate yields a total of $\$ 620$ million. A rough estimate of the total annual cost of investment mistakes of Swedish households is thus $\$ 2.8$ billion, slightly above 1 percent of Swedish GDP in 2002. While the loss of the median Swedish household is low, the total is a large number. ${ }^{8}$

Campbell (2006) discusses several reasons why Swedish households are likely to invest better than households in other countries (Tables 1 and 3 show that Sweden is the advanced economy with the highest share of participants in risky financial markets). If this is the case, one percent of GDP could be a lower bound for the overall cost of investment mistakes in other countries. These considerations suggest that there are large potential gains from policies that increase the efficiency of household investment strategies.

French (2008) estimates the cost of active investing in the US for the 1980-2007 period. ${ }^{9}$ He finds that these costs have been roughly constant, hovering around 60-70 basis points of total equity market capitalization. Using data for 2007, he estimates that a complete switch of all US-based equity investors from active to passive investment strategies would yield saving of about $\$ 109$ billion. ${ }^{10}$

If we apply French's (2008) estimates of the cost of active investing to market capitalization in 2014 (about $\$ 29$ trillion), we obtain a cost of active investment of about $\$ 191$ billion. French also estimates that the present value of the savings brought about by switching to passive investing would amount to approximately 10 percent of market capitalization (i.e.,

\footnotetext{
${ }^{7}$ This figure does not take into account management fees charged by mutual funds. Calvet et al. (2007) suggest that including these fees would not have a large effect on average investment losses in Sweden. Below, I show that in the US managment fees are substantial.

${ }^{8}$ This figure is somewhat inflated by the presence of fat tails in the distribution of losses, with a small number of investors who realize very large losses.

${ }^{9} \mathrm{His}$ strategy consists of evaluating the cost of active and passive investment and then assessing the potential savings that could be achieved by moving from active to passive investment.

${ }^{10}$ Obtained as 0.66 percent of $\$ 16.5$ trillion. Given the large share of non-residents that participate in the US capital market, this figure should not be compared with US GDP.
} 
nearly $\$ 3$ trillion using end of 2014 data).

French's calculations cover the whole US equity market. I obtain comparable results by concentrating on the US mutual fund industry. In 2014 US investors held $\$ 11$ trillion of actively managed mutual funds (equity, bond, and hybrid) and $\$ 2$ trillion of indexed mutual funds (Table 5). Average fees for managed funds were 86 and 63 basis points (for equity and bond funds, respectively) and average fees for indexed funds were 11 basis points. If all investors were to migrate to indexed funds, average fees as a percentage of total assets would drop by 55 basis points, corresponding to a savings of nearly $\$ 73$ billion (Table 6 ).

Table 5: Assets and fees in the US mutual fund industry

\begin{tabular}{|c|c|c|c|c|c|c|c|c|c|}
\hline \multirow[b]{3}{*}{ Year } & \multicolumn{4}{|c|}{$\begin{array}{l}\text { Net Assets (Bil. USD) } \\
\text { USA }\end{array}$} & ROW & \multicolumn{4}{|c|}{$\begin{array}{l}\text { Fees (bps) } \\
\text { USA }\end{array}$} \\
\hline & \multicolumn{2}{|c|}{ Equity } & \multicolumn{2}{|c|}{ Bond \& Hybrid } & \multirow{2}{*}{ All } & \multicolumn{2}{|c|}{ Equity } & \multicolumn{2}{|c|}{ Bond \& Hybrid } \\
\hline & Active & Index & Active & Index & & Active & Index & Active & Index \\
\hline 2000 & 3,577 & 357 & 1,158 & 27 & & 106 & 27 & 78 & 21 \\
\hline 2001 & 3,058 & 334 & 1,261 & 36 & & 108 & 25 & 77 & 21 \\
\hline 2002 & 2,361 & 281 & 1,430 & 46 & & 109 & 25 & 76 & 21 \\
\hline 2003 & 3,249 & 404 & 1,658 & 51 & & 110 & 25 & 77 & 21 \\
\hline 2004 & 3,849 & 494 & 1,791 & 60 & & 105 & 24 & 75 & 19 \\
\hline 2005 & 4,337 & 548 & 1,909 & 71 & & 101 & 21 & 71 & 18 \\
\hline 2006 & 5,168 & 665 & 2,144 & 83 & & 98 & 19 & 69 & 17 \\
\hline 2007 & 5,665 & 748 & 2,395 & 107 & 14,130 & 95 & 17 & 67 & 16 \\
\hline 2008 & 3,156 & 481 & 2,013 & 121 & 9,316 & 94 & 17 & 65 & 16 \\
\hline 2009 & 4,195 & 678 & 2,766 & 158 & 11,832 & 99 & 17 & 67 & 16 \\
\hline 2010 & 4,773 & 824 & 3,240 & 193 & 12,878 & 96 & 15 & 67 & 14 \\
\hline 2011 & 4,357 & 856 & 3,489 & 238 & 12,169 & 92 & 14 & 66 & 13 \\
\hline 2012 & 4,908 & 1,031 & 4,139 & 281 & 13,792 & 92 & 13 & 65 & 11 \\
\hline 2013 & 6,334 & 1,429 & 4,249 & 305 & 15,012 & 89 & 12 & 65 & 10 \\
\hline 2014 & 6,634 & 1,680 & 4,440 & 373 & 15,529 & 86 & 11 & 63 & 11 \\
\hline
\end{tabular}

Source: Own elaborations based on data from http://www.icifactbook.org

French (2008) discusses several reasons why his estimates are likely to be a lower bound of the actual costs of active investment. ${ }^{11}$ One additional cost is the interest margin of intermediaries. However, he points out that one key non-monetary cost of active investment is that active investors are not well-diversified (see investment mistake II). Therefore, these investors could increase their returns and lower their risk by switching to a passive market portfolio index, even if this index charged the same expenses of an actively managed fund.

\footnotetext{
${ }^{11}$ Along similar lines the fees reported in Tables 5 and 6 are likely to underestimate the actual cost of actively managed mutual funds, see Edelen et al. (2013)
} 
Table 6: Potential savings from switching to indexed funds

\begin{tabular}{|c|c|c|c|c|c|c|c|c|c|}
\hline \multirow[b]{3}{*}{ Year } & \multicolumn{5}{|c|}{ Fees (billion USD) } & \multicolumn{4}{|c|}{ Potential Savings } \\
\hline & \multicolumn{2}{|c|}{ Equity } & \multicolumn{2}{|c|}{ Bond \& Hybrid } & \multirow[t]{2}{*}{ Total US } & \multicolumn{2}{|c|}{ USA } & \multirow{2}{*}{$\begin{array}{r}\text { ROW } \\
\text { Bil }\end{array}$} & \multirow{2}{*}{$\begin{array}{l}\text { Total } \\
\text { USD }\end{array}$} \\
\hline & Active & Index & Active & Index & & Bil USD & $\% \mathrm{TA}$ & & \\
\hline 2000 & 37.92 & 0.96 & 9.03 & 0.06 & 47.97 & 34.86 & $0.68 \%$ & & \\
\hline 2001 & 33.03 & 0.84 & 9.71 & 0.08 & 43.65 & 32.44 & $0.69 \%$ & & \\
\hline 2002 & 25.73 & 0.70 & 10.87 & 0.10 & 37.40 & 27.70 & $0.67 \%$ & & \\
\hline 2003 & 35.74 & 1.01 & 12.77 & 0.11 & 49.62 & 36.90 & $0.69 \%$ & & \\
\hline 2004 & 40.41 & 1.19 & 13.44 & 0.11 & 55.15 & 41.21 & $0.67 \%$ & & \\
\hline 2005 & 43.81 & 1.15 & 13.55 & 0.13 & 58.64 & 44.81 & $0.65 \%$ & & \\
\hline 2006 & 50.65 & 1.26 & 14.79 & 0.14 & 66.85 & 51.98 & $0.64 \%$ & & \\
\hline 2007 & 53.82 & 1.27 & 16.04 & 0.17 & 71.30 & 56.40 & $0.63 \%$ & 89.40 & 145.80 \\
\hline 2008 & 29.67 & 0.82 & 13.08 & 0.19 & 43.76 & 34.17 & $0.59 \%$ & 55.16 & 89.32 \\
\hline 2009 & 41.53 & 1.15 & 18.53 & 0.25 & 61.47 & 48.51 & $0.62 \%$ & 73.61 & 122.12 \\
\hline 2010 & 45.82 & 1.24 & 21.71 & 0.27 & 69.03 & 55.83 & $0.62 \%$ & 79.63 & 135.46 \\
\hline 2011 & 40.09 & 1.20 & 23.03 & 0.31 & 64.62 & 52.48 & $0.59 \%$ & 71.43 & 123.91 \\
\hline 2012 & 45.16 & 1.34 & 26.91 & 0.31 & 73.71 & 61.13 & $0.59 \%$ & 81.39 & 142.52 \\
\hline 2013 & 56.37 & 1.71 & 27.62 & 0.30 & 86.01 & 72.14 & $0.59 \%$ & 87.93 & 160.07 \\
\hline 2014 & 57.06 & 1.85 & 27.97 & 0.41 & 87.28 & 72.84 & $0.55 \%$ & 86.17 & 159.02 \\
\hline
\end{tabular}

If we were to assume that mutual funds in the rest of the world had the same composition and fee structure of US mutual funds, worldwide migration to index funds would entail a saving of $\$ 160$ billion (last two columns of Table 6 ). This is likely to be a lower bound for world-level savings because in most countries average mutual fund fees (not adjusted for composition) are higher than in the US (Table 7).

French (2008) recognizes that moving all investment to index funds would not be optimal for society because active trading is necessary for price discovery. While it is impossible to assess whether, at $\$ 191$ billion per year, society invests too much or too little in price discovery, price discovery is an externality and it is not clear why individual investors are willing to pay for it. From the point of view of individual investors, active investment is clearly a mistake.

\section{The roots of investment mistakes}

Why don't households participate in risky asset markets? Why don't they diversify? Why do they pay a premium for financial advice that delivers sub-par performance? 


\section{Table 7: Total expense ratio of mutual funds in 17 countries}

\begin{tabular}{lcc}
\hline \hline Country & By country of domicile & By country of sale \\
\hline Australia & 1.17 & 1.17 \\
Austria & 0.76 & 1.17 \\
Belgium & 0.88 & 1.10 \\
Canada & 2.20 & 2.20 \\
Denmark & 1.00 & 1.54 \\
Finland & 0.99 & 1.50 \\
France & 0.77 & 1.02 \\
Germany & 1.05 & 1.09 \\
Italy & 1.23 & 1.27 \\
Luxembourg & 1.22 & 1.16 \\
Netherlands & 0.64 & 1.29 \\
Norway & 1.89 & 1.47 \\
Spain & 1.29 & 1.29 \\
Sweden & 1.19 & 1.43 \\
Switzerland & 1.39 & 1.19 \\
UK & 2.18 & 1.29 \\
US & 0.95 & 0.81 \\
Average & $\mathbf{1 . 2 2}$ & $\mathbf{1 . 3 5}$ \\
\hline \hline
\end{tabular}

Source: Table 2 of Khorana et al. (2008).

The most likely explanation for non-participation at low levels of wealth is the presence of fixed costs which include charges for opening an account but also information and monitoring costs (Vissing-Jørgensen 2003). Lack of knowledge is also an issue. Guiso and Jappelli (2005) show that some households are not aware of stocks as an asset class and that stock ownership is positively correlated with education. Using surveys covering more than 1200 US residents, Lusardi and Mitchell (2006 and 2007) find that only a minority of respondents (44 percent of total) could provide correct answers to five simple financial questions. The share of respondents who answered these questions correctly was lower for women, minorities, and low-income individuals.

Small transaction and information costs cannot explain non-participation of wealthy households. Non-participation can instead be explained by the fact that costs related to investing in risky assets may have a subtler psychological nature.

Loss aversion refers to a situation in which the pain that an investor feels from a loss is much stronger than the pleasure from an equivalent gain (Kahneman and Tversky 1979). Loss aversion, which already reduces investors' willingness to take compensated risk, is 
amplified by myopia (i.e., the tendency to evaluate outcomes more frequently than needed). Experimental evidence shows that these two factors lead to suboptimal risk-taking and investment performance (Benartzi and Thaler 1995 and Thaler et al. 1997).

Breuer et al. (2010) explore the factors that make equity ownership uncomfortable for some households and conclude that psychological factors rooted in national culture affect portfolio choice and willingness to take financial risk. Along similar lines, lab experiments find that trust increases willingness to take risk (Karlan 2005 and Schechter 2007). Guiso et al. (2008) show that willingness to participate in the stock market is positively correlated with trust in other people and Hong et al. (2004) find that households who have stronger social interactions with other households in their community are more likely to hold risky financial assets.

Since trust is not strongly correlated with wealth, the close link between participation and trust can explain non-participation among the wealthy. It can also explain large crosscountry differences in participation (Guiso and Sodini 2013).

Like non-participation, underdiversification can be the outcome of fixed learning and transaction costs (Brennan 1975). There is also evidence of "brand loyalty." Investors are more likely to buy stocks of companies that produce their favorite products and services, and portfolios composed by these stocks underperform. This finding supports Fama and French's (2007) idea that many households consider financial assets as consumption goods.

We also saw that the incentives of financial advisors are not always aligned with those of their clients. Why are investors willing to pay for advice that leads to undeperformance? Gennaioli et al. (2015) suggest that it is because money managers provide peace of mind. In a first best world, households would just invest in passive index funds. However, anxiety may prevent investors from participating in risky assets and money managers provide a valuable service because, with peace of mind, investors are more likely to take risk and earn higher returns. In this sense, money managers are second-best optimal.

Summing up, investment mistakes are likely to be the outcome of cognitive biases and limitations and distorted incentives in the financial industry. These biases and limitations 
are likely to be very important in making financial decisions because such decisions are made infrequently and have delayed outcomes (Campbell et al. 2011). It is also difficult to learn from others because people do not like to disclose information about their financial situation.

Any proposal that aims at reducing investment mistakes needs to acknowledge and accommodate these biases and distorted incentives. It needs to be salient, increase trust, focus on an investment strategy with low monetary and psychological transaction costs, and inform investors about the possibly distorted incentives of financial advisors.

\section{Reducing investment mistakes}

This section describes a simple proposal aimed at reducing the prevalence and cost of investment mistakes. The proposal combines financial education with a list of pre-approved funds (either mutual funds or ETFs) that meet the criteria for optimal investment.

In many countries potential investors are required to complete forms aimed at assessing their degree of risk aversion and ability to understand and bear risk. These forms, however, do not give specific guidance on what investors should do. I propose to provide investors with such specific guidance. The proposal is related to Swensen's (2005) idea of subsidizing low-cost passive mutual funds. However, instead of using tax incentives, I suggest to nudge (Sunstein and Thaler 2008) households towards efficient investment with an information campaign and appropriate default options while maintaining complete freedom of choice. ${ }^{12}$

Financial education should be simple, specific, and delivered when households are ready to invest. I propose that before making any investment decision, investors should be asked to read a simple leaflet that describes common investment mistakes and provides specific advice on optimal investment strategies. The specific advice will include the optimal share of financial wealth that should be invested in risky assets and the type of risky assets that households should buy (low-fee passively-managed funds that track a global index of

\footnotetext{
${ }^{12}$ The proposal is also related to Choi et al.'s $(2002,2004)$ work on default options in retirement saving plans.
} 
stocks). The leaflet will also include endorsements from autoritative bodies and institutions with strong reputation and no obvious conflict of interest (Choi et al. 2002, 2004, show that such endorsements influence household behavior), a list of investment funds that satisfy the requirements for efficient investment, and an explanation that these funds can be bought with a small minimum investment (\$50 in my example). The Appendix includes an example of the leaflet (this is a rough draft, the actual flyer will need to be designed by marketing experts).

After reading the leaflet, investors will be asked to answer two or three simple questions aimed at assessing their comprehension of the material and then they will be free to make whatever investment decision they want -even if it deviates from the efficient investment strategy suggested in the leaflet. This latter element is essential for maintaining freedom of choice.

There are two approaches to financial education: standard training and rule-of-thumb. Standard training focuses on the basic of investing and educates households on the property of compound interest, risk diversification, etc. Rule-of-thumb training consists of providing simple routines or heuristics for decision-making. Available evidence suggests that standard financial education is not very effective in altering behavior, possibly because of status quo bias and information overload (World Bank 2013a, Drexler et al. 2014). An experiment in the Dominican Republic has instead shown that rule-of-thumb education is effective in altering the behavior of small entrepreneurs, with an especially large effect for less sophisticated entrepreneurs (Drexler et al. 2014).

My proposal recognizes these cognitive biases and addresses them by using a simple default option (to deal with information overload) and by delivering financial education when it is most salient and that can be enhanced with a learning by investing component.

The proposal also recognizes that the interests of financial institutions and financial advisors are not always aligned with those of investors (see above). Financial institutions and advisors often have incentives to promote inefficient high-fees managed investment products. However, it may be difficult to push such products to potential investors who have 
just read a leaflet stating that investing in actively managed financial products is generally not a good idea. This is the case even if the leaflet does not provide new information. There is a psychological cost in confronting a financial advisor who is providing bad advice and the leaflet may reduce this cost. The "common knowledge" situation (I know that you know, you know that I know that you know, ...) can change the equilibrium of the game between clients and financial advisors (Lewis 1969 and Aumann 1976).

One drawback of providing advice when households are ready to invest is that this strategy misses all households that are not even thinking about investing. This problem could be addressed by placing posters in banks and post offices and with TV and press campaigns. It would also be possible to send the leaflet with bank statements, explaining that this is not an advertisement campaign of the bank but a public initiative endorsed by all the organizations listed in the flyer.

The proposal is based on a simple rule of thumb investment strategy which does not consider differences in ownerships of real assets and labor income shocks. ${ }^{13}$ However, shocks to labor income are mostly idiosyncratic (therefore, non-diversifiable and almost irrelevant for investment decisions) and research based on direct stock ownership does not find any evidence that households use their financial portfolio to hedge income shocks (Massa and Simonov 2006).

A robust result of the literature on financial education is that "simple is better" (Karlan et al. 2014). Therefore, instead of being a problem, a simple default investment option is likely to increase participation while allowing sophisticated investors to be as flexible as they want to be.

Non-participation in risky assets might be driven by mistrust in banks and financial institutions. For instance, Coupe (2011) finds that more than 50 percent of Ukrainian households save in cash and that households who self-report as having low trust in banks are 10 to 15 percentage points more likely to keep all their savings in cash at home. One way to address this problem and reach a larger number of potential households is to issue

\footnotetext{
${ }^{13}$ The proposal assume that investors will adjust their portfolio with age. An alternative is to use "target date funds."
} 
low value (say $\$ 50$ ) physical bearable certificates that households can buy and sell without any fee in banks and post offices at a price that is fixed daily and is widely disseminated in newspapers and on the internet and TV. ${ }^{14}$

\section{Challenges}

I see three main challenges to the proposal described in this paper.

\section{Lobbying}

A massive move to low-fee index trackers is likely to be disruptive for individuals and institutions that benefit from the status quo. Banks may suffer because deposits, which are a source of cheap funds, may shrink. Providers of managed financial products may lose clients and fee income. Sophisticated investors may lose benefits arising from crosssubsidies within the financial industry (Gabaix and Liabson 2006). Governments will face more competition for funds and possibly face higher borrowing costs. ${ }^{15}$

Therefore, these agents may decide to lobby against the proposal described in this paper. The best way to contrast this lobbying effort is to engage with consumer associations. Another good idea would be to start with a small program and subject it to a rigorous evaluation using the randomized control techniques that are common in development economics.

\section{Large losses}

A worldwide equity market crash soon after the inception of the program would be disastrous for the program (and for the households who invested in it).

\footnotetext{
${ }^{14} \mathrm{~A}$ possible problem with having physical bearable units is that they may substitute cash for illegal transactions. This is why they should not be issued in large denominations. An alternative would be to have simple internet platforms which allow investors to buy and sell the simple financial products described in this paper.

${ }^{15}$ The literature on financial repression (Reinhart and Sbrancia 2015) shows that governments have used all sort of methods to induce residents to buy financial instruments that yield low (or even negative) real returns.
} 
One way to deal with this issue is a gradual implementation of the program. One could envisage a situation in which households who never held risky assets are suggested to invest a very small share (much smaller than what would be optimal) of their financial wealth in risky assets. While a negligible allocation of financial wealth in risky assets would not have any impact (either positive or negative) on total wealth, it would change the status quo.

Status quo bias (Samuelson and Zeckhauser 1988) is a robust result in behavior economics. A policy that induces households to move from no investment in risky assets to some investment in risky assets (even if the level of investment in risky assets is negligible) could change the status quo and have a powerful effect on financial education (remember that Tables 1- 3 show that in most countries only a minority of households invests in risky assets). As households learn by investing, they will feel more comfortable in taking more risky assets in their portfolio and also acquire the peace of mind which may set them free from costly money doctors (Gennaioli et al. 2015).

\section{Less price discovery and innovation}

Active traders provide a service to society because they contribute to price discovery, supply liquidity to the market, and may contribute to the development of innovative financial products (however, there is also the view that too much trading can increase volatility). Therefore, there is the risk that a massive shift to index products may result in prices that are misaligned with fundamentals and stifle financial innovation. A large shift to index tracking may also crystallize the status quo (who decides what is in the index?), possibly giving an unfair advantage to incumbents and starving new companies and frontier markets that need financing to grow.

While these considerations suggest that my proposal may become a victim of its own success, it is worth pointing out that the benefits of financial innovation have been elusive. ${ }^{16}$ Moreover, at the margin there will always be incentives to identify misspriced assets. How-

\footnotetext{
${ }^{16}$ Paul Volcker once asked: "How many other innovations can you tell me that have been as important to the individual as the automatic teller machine, which in fact is more of a mechanical than a financial one?" Litan (2010) provides a more positive view of financial innovation.
} 
ever, the question raised above (is price discovery worth $\$ 190$ billion per year?) is indeed an important question.

A related issue is that a massive reduction in home bias may lead to possibly destabilizing flows to emerging market countries and reduce bank lending to small and medium enterprises. I briefly discuss these problems in the next section.

\section{$8 \quad$ Growth and macro-level effects}

There are several channels through which greater participation in risky assets may have a positive effect on growth and welfare.

\section{Cost of capital}

The first and most basic of these channels is greater investment brought about by a reduction in the cost of capital. Table 8 reports data on equity premia in 21 advanced economies and 17 emerging markets. The average equity premium in the first group of countries is 6.3 percent (ranging between 2 percent in New Zealand and 17 percent in Greece) and the average premium in emerging markets is 12 percent (ranging between 3 percent in Indonesia and 25 percent in Chile).

Greater participation in risky assets would reduce these equity premia and, through a standard Tobin's Q argument, increase investment. If at least part of this investment is productive, countries will transition to higher steady-state income and experience higher GDP growth during the transition period.

This channel is likely to be especially beneficial for emerging market countries that have larger equity premia and may receive large inflows if investors in advanced economies reduce their home bias.

Such transition, however, may also entail risks and its general equilibrium consequences will need to be carefully explored with a formal model. Massive flows to risky assets can create bubbles and feed into a "this time is different" attitude that, as documented by Reinhart and Rogoff (2009), always leads to tragedy. Flows to emerging market countries 
Table 8: Equity premium

\begin{tabular}{lcclcc}
\hline \hline \multicolumn{3}{c}{ Advanced Economies } & & \multicolumn{2}{c}{ Emerging Markets } \\
Country & Period & Premium & Country & Period & Premium \\
\hline Australia & $1900-2005$ & $7.08 \%$ & Argentina & $1980-2000$ & $14.31 \%$ \\
Austria & $1970-2000$ & $5.42 \%$ & Chile & $1974-2000$ & $24.64 \%$ \\
Belgium & $1900-2005$ & $2.80 \%$ & Colombia & $1973-2000$ & $9.93 \%$ \\
Canada & $1900-2005$ & $4.54 \%$ & Hong Kong & $1970-2000$ & $21.97 \%$ \\
Denmark & $1900-2005$ & $2.87 \%$ & India & $1970-2000$ & $6.41 \%$ \\
Finland & $1970-2000$ & $18.51 \%$ & Indonesia & $1977-2000$ & $3.31 \%$ \\
France & $1900-2005$ & $6.79 \%$ & Israel & $1970-2000$ & $7.36 \%$ \\
Germany & $1900-2005$ & $3.83 \%$ & Korea & $1977-2000$ & $9.74 \%$ \\
Greece & $1980-2000$ & $16.58 \%$ & Malaysia & $1975-2000$ & $10.47 \%$ \\
Ireland & $1900-2005$ & $4.09 \%$ & Mexico & $1970-2000$ & $17.11 \%$ \\
Italy & $1900-2005$ & $6.55 \%$ & Pakistan & $1970-2000$ & $4.44 \%$ \\
Japan & $1900-2005$ & $6.67 \%$ & Peru & $1970-2000$ & $24.24 \%$ \\
Netherlands & $1900-2005$ & $4.55 \%$ & Philippines & $1970-2000$ & $12.04 \%$ \\
New Zealand & $1970-2000$ & $2.10 \%$ & Singapore & $1970-2000$ & $14.55 \%$ \\
Norway & $1900-2005$ & $3.07 \%$ & South Africa & $1900-2005$ & $6.20 \%$ \\
Portugal & $1979-2000$ & $14.98 \%$ & Taiwan & $1976-2000$ & $12.37 \%$ \\
Spain & $1900-2005$ & $3.40 \%$ & Thailand & $1975-2000$ & $9.56 \%$ \\
Sweden & $1900-2005$ & $5.73 \%$ & & & \\
Switzerland & $1900-2005$ & $3.63 \%$ & Average EM & & $\mathbf{1 2 . 2 7 \%}$ \\
UK & $1900-2005$ & $4.43 \%$ & Average AE & & $\mathbf{6 . 3 4 \%}$ \\
US & $1900-2005$ & $5.51 \&$ & Average ALL & & $\mathbf{8 . 9 9 \%}$ \\
\hline \hline Sorce & $1900-205$ & & & & \\
\hline
\end{tabular}

Source: data for 1900-2005 are from Dimson et al. (2008), post 1970 data are from Shackman (2005)

can also lead to currency appreciation and financial protectionism. Flows to risky assets are also likely to reduce bank deposits and, in turn, bank lending. This could be a good thing if lower bank lending leads to lower housing finance (a key driver of real estate bubbles, Jordà et al. 2015). However, it could be bad news for small and medium enterprises which disproportionately rely on bank financing.

\section{Greater risk-sharing}

Lower home bias will also increase international risk-sharing (which remains low even in an era of financial globalization, Kose et al. 2006). The effect of risk-sharing on growth is, however, ambiguous. In a model with precautionary savings, lower risk decreases savings and, in a neoclassical model, it has a negative effect on steady-state income (and growth 
during the transition to the new steady state). However, risk-sharing may also channel savings into riskier but more productive technologies and thus have a positive effect on growth. In a calibrated model, Femminis (2001) finds that the latter effect dominates the former.

Recent attempts to estimate the growth and welfare impact of risk-sharing through financial globalization found heterogeneous effects which depend on the structure of shocks, the size of countries, and their initial degree of capital scarcity (Courdacier et al., 2015). ${ }^{17}$

\section{A different type of portfolio flows for closing the infrastructure gap}

A common result in the literature on the growth effects of financial globalization is that while foreign direct investments (FDI) have a positive effect on growth, portfolio flows have no effect on growth and may have negative effects in terms of increasing capital account volatility and the probability of financial crises. ${ }^{18}$ Hence, economists and policymakers are often comfortable with policies that do not pose any limit to FDI inflows but are more cautious in advocating full capital account liberalization. ${ }^{19}$ The Original Washington Consensus (Williamson 1990) stated that:

As noted above, liberalization of foreign financial flows is not regarded as a high priority. In contrast, a restrictive attitude limiting the entry of foreign direct investment (FDI) is regarded as foolish. Such investment can bring needed capital, skills, and know-how, either producing goods needed for the domestic market or contributing new exports.

While FDI flows have the advantages listed above, they also tend to be expensive and can lead to large return differentials (see, among others, Hausmann and Sturzenegger 2007 and Gourinchas and Rey 2007). Ostry et al. (2010) also point out that FDIs may be less safe than commonly thought because they include intragroup debt.

\footnotetext{
${ }^{17}$ Courdacier et al. (2015) find that safe countries benefit the most from integration with risky countries.

${ }^{18}$ For a recent discussion on the links between financial crises and growth see Reinhart and Reinhart (2015).

${ }^{19}$ For a recent discussion of the pros and cons of capital controls see Ostry et al. (2010).
} 
With lower equity premia, portfolio equity flows would have the advantage of being cheaper than FDIs while maintaining the contingent nature of FDIs (which, unlike external debt, do not require fixed payments in foreign currency). Moreover, a world populated by internationally diversified passive investors should be characterized by much lower volatility with respect to the status quo, making portfolio flows an attractive form of financing.

OECD (2006) and World Bank (2013b) show that large infrastructure gaps are an obstacle to growth in both developing and advanced economies. These studies also suggest that the private sector needs to play a role in closing these gaps. However, infrastructure projects require financial instruments with long maturity and denominated in local currency (because most infrastructure projects produce non-tradable services), and there is limited demand for these types of instruments (Group of Thirty 2013). The policy described in this paper could contribute to creating demand for these instruments and is in line with the Group of Thirty (2013, p. 55) proposal of:

Increasing the ability of households to place savings in capital markets by promoting the use of mutual funds, exchange-traded funds, and retail brokerages. Provide widespread consumer financial education initiatives to explain the benefits of diversified sources of savings and of compounded annual returns.

\section{Distributional effects}

The careful reader will have noted a tension between the main benefit listed in this section (higher income brought about by lower cost of capital) and the main benefit of holding risky assets discussed in the previous section (higher risk-adjusted returns). In a perfect world there wouldn't be an equity premium puzzle and the differential between the returns of risky and safe assets would be fully consistent with standard risk-aversion measures.

While we are far from a perfect world (and we will be far from it for a long time), it is worth thinking about the distributional consequences of the policy advocated in this 
paper. $^{20}$

Given that under the status quo risky assets are held by the wealthy, greater participation in risky assets (which will increase their price and lower their return) will have an ambiguous effect on the portfolio of the rich. ${ }^{21}$ The effect on the middle-class who moves from low to high return assets should, instead, be unambiguously positive. The poorest segments of the population may still decide not to hold any financial assets. Therefore, they will not be affected by this policy, unless the shift to risky assets leads to an increase in the interest rate of government bonds and the government decides to compensate for higher borrowing costs with regressive taxes or less social expenditure.

A widespread shift to index investing is also likely to reduce average income in the financial industry. Given that wages in the financial industry tend to be high (Philippon and Reshef 2012), such a transition will reduce income inequality.

Campbell et al. (2011) discuss the distributional consequences of consumer financial protection and conclude that, if successful, such policy is likely to reallocate resources from sophisticated (and richer) to naive (and generally poorer) households.

\section{Conclusions}

Households make costly investment mistakes. Active investment strategies underperform with respect to low cost funds that track the market portfolio. Yet, US-based investors spend nearly $\$ 200$ billion in fees related to active investment strategies. These fees are only part of the total cost of investment mistakes. Swedish data (the only country for which we have detailed information) show that the costs of non-participation and underdiversification add up to one percent of GDP. As US and Swedish households are likely to be more financially sophisticated than households in other countries, one percent of GDP ( $\$ 450$ billion) is

\footnotetext{
${ }^{20}$ What follows assumes that the growth effect discussed above has no effect on income inequality (Dollar and Kraay 2002).

${ }^{21}$ There will be an immediate capital gain and lower returns in the future. These two effects will compensate each other for existing holdings but the rich will suffer from lower returns when they increase their holdings of risky assets. However, if the rich also make investment mistakes (in terms of taking uncompensated risk), an indexed portfolio may increase their risk-adjusted returns.
} 
probably a lower bound for the total cost of investment mistakes in advanced economies.

Investment mistakes also tend to be regressive because financial sophistication is positively correlated with wealth and education. Therefore, a policy that reduces investment mistakes is likely to reduce income and wealth inequality (this effect, however, is likely to be small).

The proposal described in this paper is based on results in economics and finance that emphasize behavioral biases like loss aversion, myopia, status quo bias, and lack of trust. It also incorporates recent evidence that financial literacy programs based on simple heuristics, rule-of-thumb strategies, and default options are more effective than traditional education programs. Finally, it recognizes that there is often a conflict of interest between financial advisors and retail investors because the former may have monetary incentives to sell complex financial products that have high fees and often underperform with respect to the market portfolios.

The proposal builds on the idea that information needs to be easy to understand and salient. It uses a simple learning-by-investing program which aims at reducing the transaction, information, and psychological costs of investing in high-return risky financial assets. The policy can even be effective if does not provide new information because, by creating "common knowledge," it reduces the psychological cost of confronting a financial advisor who is providing bad advice. ${ }^{22}$

The policy described in this paper is immediately actionable at no cost (or at a very low cost) and can have a large effect on the welfare of middle-class households in advanced economies.

\footnotetext{
${ }^{22}$ Friends who have PhDs in economics and who know perfectly well that active investment is a bad idea, told me that when their financial advisor comes up with strange investment ideas which are clearly aimed at maximizing fees (instead of returns), they feel a psychological discomfort in confronting the advisor. The outcome is that they either do not invest or end up investing is sub-optimal financial products.
} 


\section{A Example of Flyer}

Below is an example of the content of flyer advocated in this paper. The actual flyer will need to be designed by marketing experts and its content will be tested with focus groups and adapted to the national context.

\section{How to Make the Most of Your Savings}

Investing your savings can be both intimidating and confusing. Most households, rich and poor, make costly mistakes when they manage their savings.

This flyer illustrates the most common investment mistakes and suggests a simple strategy for avoiding these mistakes and improving how you manage your savings. Its content is based on a vast body of research in economics and finance and has been approved by: LIST OF REPUTABLE BODIES AND INSTITUTIONS.

Investment mistake I: Households are exceedingly conservative with their savings. Taking too much risk is always a bad idea, but research shows that most households would benefit from allocating part of their savings to financial assets that, at the cost of higher volatility, offer higher average returns. Over the medium and long run a well-diversified investment in stocks outperforms holding money in bank deposits or government bonds.

The share of assets to be allocated to high return assets depends on individual household circumstances and total wealth. However, even households with limited financial wealth should hold some high return financial assets. The table in the back of this flyer provides a guide for allocating financial wealth into high-return risky assets and lower return safer assets.

Investment mistake II: Households who buy risky assets do not diversify enough. Households who buy equities often hold a small number of stocks, which tend to be of domestic companies or even of companies that are geographically close to the household. Households who buy mutual funds often hold mutual funds that overwhelmingly invest in domestic companies. Research shows that households should invest in a globally diversified portfolio of stocks that includes companies located in all countries and world regions, where the weight of each stock is equal to its share in the total capitalization of the world equity market.

Investment mistake III: Households who buy risky assets are sometimes too active in buying and selling stocks. Excessive trading may lead to suboptimal performance and asset misallocation. Research shows that households should invest in a globally diversified portfolio of stocks that includes companies located in all countries and world regions and should only buy and sell to rebalance their portfolio according to the investment shares illustrated by the table in the back of this flyer. 
Investment mistake IV: Households sometimes buy managed investment products with high fees and suboptimal returns. Financial advisors and institutions may have an incentive to sell products (either mutual funds or managed wealth products) with actively managed investment positions. On average, these products do not yield superior returns (compared with overall market return) and, because of high fees, often yield returns that are substantially lower than the market return. Research shows that households should invest in low-fee passively-managed funds that track a global index of stocks that includes companies located in all countries and world regions where the weight of each stock is equal to its share in the total capitalization of the world equity market.

\section{Avoiding investment mistakes}

There is a simple strategy to avoid the four investment mistakes listed above. You should allocate part of your financial wealth to higher return risky assets by investing in a low fee passively managed globally diversified portfolio of stocks that includes companies located in all countries and world regions where the weight of each stock is equal to its share in the total capitalization of the world equity market.

The table in the back of this is flyer will help you in deciding what share of your financial wealth should be invested in high-return risky financial assets. Below the table you will find a list of low-fee passively-managed internationally diversified funds that meet the requirements for optimal investment. Each of these funds can be bought with a minimum investment of $\$ 50$.

You should be aware that there is always a risk involved in investing in high-return assets. As a consequence you should avoid taking too much risk by exceeding the investment shares reported in the table.

You (and your financial advisor) may have investment ideas that deviate from the suggestions of this leaflet and, of course, you are free to act on these ideas. However, you should be aware that by doing so you are likely to deviate from best practices in household financial investment and that sometimes financial advisors have monetary incentives linked to selling high-fee products which end up underperforming the simple investment strategy proposed in this flier. You should ask your financial advisor about this potential conflict of interest. 
Allocation of financial wealth

$(\text { share of risky assets })^{23}$

\begin{tabular}{lccccccc}
\hline \hline & & & Age group & & \\
$\mathbf{S} / \mathbf{Y}$ & $\mathbf{2 0 - 3 0}$ & $\mathbf{3 1 - 4 0}$ & $\mathbf{4 1 - 5 0}$ & $\mathbf{5 1 - 6 0}$ & $\mathbf{6 1 - 6 5}$ & $\mathbf{6 6 - 7 0}$ & $>\mathbf{7 0}$ \\
\cline { 2 - 8 }$<\mathbf{2}$ & $0.40-0.70$ & $0.40-0.70$ & $0.35-0.65$ & $0.30-0.60$ & $0.25-0.55$ & $0.20-0.50$ & $0.15-0.50$ \\
$\mathbf{2 - 1 2}$ & $0.45-0.75$ & $0.45-0.75$ & $0.40-0.70$ & $0.35-0.65$ & $0.30-0.60$ & $0.30-0.55$ & $0.20-0.50$ \\
$\mathbf{1 2 - 1 8}$ & $0.50-0.80$ & $0.50-0.80$ & $0.45-0.75$ & $0.40-0.70$ & $0.35-0.65$ & $0.30-0.60$ & $0.25-0.55$ \\
$\mathbf{1 8 - 2 4}$ & $0.60-0.90$ & $0.60-0.90$ & $0.55-0.85$ & $0.50-0.80$ & $0.45-0.75$ & $0.40-0.70$ & $0.30-0.60$ \\
$\mathbf{2 4 - 3 6}$ & $0.65-0.90$ & $0.60-0.90$ & $0.60-0.90$ & $0.55-0.85$ & $0.50-0.80$ & $0.45-0.75$ & $0.35-0.65$ \\
$>\mathbf{3 6}$ & $0.70-0.90$ & $0.70-0.90$ & $0.65-0.90$ & $0.60-0.85$ & $0.55-0.85$ & $0.50-0.80$ & $0.40-0.70$ \\
\hline \hline
\end{tabular}

$\mathrm{S} / \mathrm{Y}=$ Financial savings divided by monthly disposable income

This table provides an easy-to-use method to allocate your financial savings (defined as cash, bank accounts, mutual funds, and individual stocks and bonds) between safe low-return assets (such as bank deposits and short-term government bonds) and riskier high-return assets (a well diversified basket of stocks). Each cell gives a range for the share of risky assets, more risk-averse households should choose values close to the bottom end of this range, while households that can bear more risk should choose a value close to the upper end of the range.

For example, a households where the main income earner is 35 years old (or the average age of the main income earners is 35) and has financial savings equal to 8 times to the household's monthly income should allocate between 45 and 75 percent of its financial wealth to risky higher-return financial assets. A household with a income earner aged 45 and financial savings equal to 40 times monthly income should instead allocate between 65 and 90 of its financial wealth to risky higher return financial assets.

\section{List of Investment Funds}

Here is a list of low fee passively managed globally diversified investment funds that meet the criteria for optimal investment highlighted in the first page of this flyer.

\footnotetext{
${ }^{23}$ Note that the numbers in this table are only for illustration. Actual figures needs to be calculated and adapted across countries
} 


\section{References}

[1] Arrondel, L., Bartiloro, L., Fessler, P., Lindner, P., Mathä, T. , Rampazzi, C., Savignac, F., Schmidt, T., Schürz, M., and Vermeulen, P (2014). How do households allocate their assets? Stylised facts from the Eurosystem Household Finance and Consumption Survey. ECB WP 1722.

[2] Aumann, R. (1976) Agreeing to Disagree. Annals of Statistics, 4(6): 1236-1239.

[3] Benartzi, S. and Thaler, R. (1995). Myopic Loss Aversion and the Equity Premium Puzzle. Quarterly Journal of Economics, 110:73-92.

[4] Benartzi, S. and Thaler, R. (2013). Behavioral Economics and the Retirement Savings Crisis. Science, 339: 1152-1153.

[5] Bergstresser, D., Chalmers, J. and Tufano, P. (2009). Assessing the costs and benefits of brokers in the mutual fund industry. Review of Financial Studies, 22: 4129-4156.

[6] Brennan, M. J. (1975). The Optimal Number of Securities in a Risky Asset Portfolio When There Are Fixed Costs of Transacting: Theory and Some Empirical Results. Journal of Financial and Quantitative Analysis, 10: 483-496.

[7] Wolfgang Breuer, W., Riesener, M., and Salzmann, A. (2014). Risk aversion vs. individualism: what drives risk taking in household finance? The European Journal of Finance, 20: 446-462.

[8] Calvet, L., Campbell, J. and Sodini, P. (2007). Down or out: Assessing the welfare costs of household investment mistakes. Journal of Political Economy, 115: 707-747.

[9] Campbell, J. (2006). Household finance. Journal of Finance, 61: 1553-1604.

[10] Campbell, J., Jackson, H., Madrian. B. and Tufano, P. (2011), Consumer Financial Protection. Journal of Economic Perspectives, 25: 91-114.

[11] Chater, N., Huck, S., and Inderst, R. (2010). Consumer Decision-Making in Retail Investment Services: A Behavioural Economics Perspective. EU Report.

[12] Choi, J. J., Laibson, D., Madrian, B., and Metrick, A. (2004). For better or for worse: Default effects and 401(k) savings behavior. In D. Wise (Ed.), Perspectives on the economics of aging. Chicago IL: University of Chicago Press.

[13] Choi, J. J., Laibson, D., Madrian, B., and Metrick, A. (2009). Reinforcement learning and savings behavior. Journal of Finance, 64: 2515-2534.

[14] Choi, J. J., Laibson, D., and Madrian, B. C. (2010). Why does the law of one price fail? An experiment on index mutual funds. Review of Financial Studies, 23,:1405-1432.

[15] Coupé, T. (2010). Mattresses Versus Banks - The Effect of Trust on Portfolio Composition. Kiev School of Economics DP. 40. 
[16] Courdacier, N., Rey, H., and Winant, P. (2015). Financial Integration and Growth in a Risky World. unpublished.

[17] Dimson, P. Marsh, P., and Staunton, M. (2008). Handbook of the Equity Risk Premium, Amsterdam, Elsevier.

[18] Dollar, D. and Kraay, A. (2002). Growth is Good for the Poor. Journal of Economic Growth, 7: 195-225.

[19] Drexler, A., Fischer, G., and Schoar, A. (2014). Keeping It Simple: Financial Literacy and Rules of Thumb. American Economic Journal: Applied Economics, 6: 1-31.

[20] Edelen, R., Evans, R., and Kadlec, G. (2013). Shedding Light on "Invisible" Costs: Trading Costs and Mutual Fund Performance. Financial Analysts Journal, 69: 33-44.

[21] Fama, E. and French, K. (2007). Disagreement, Tastes, and Asset Prices. Journal of Financial Economics, 83: 667-89.

[22] Femminis, G. (2001) Risk-Sharing and Growth: The Role of Precautionary Savings in the Education Model. Scandinavian Journal of Economics, 103: 63-77.

[23] Ferri, R. and Benke, A. (2013). A case for Index Fund Portfolios. unpublished.

[24] Fecht, F., Hackethal, A., and Karabulut, Y. (2013). Is Proprietary Trading Detrimental to Retail Investors? Discussion Paper 42/2013, Deutsche Bundesbank.

[25] French, K. (2008). The cost of active investing. Journal of Finance, 63: 1537-1573.

[26] Gabaix, X., and Laibson, D. (2006). Shrouded attributes, consumer myopia, and information suppression in competitive markets. Quarterly Journal of Economics, 121: $505-540$.

[27] Gennaioli, N., Shleifer, A., and Vishny, R. (2015). Money Doctors. Journal of Finance, 70: $91-114$.

[28] Gourinchas, P. and Rey, H. (2007). From world banker to world venture capitalist: The U.S. external adjustment and the exorbitant privilege. in R.Clarida (ed.) G7 Current Account Imbalances: Sustainability and Adjustment. Chicago, Univeristy of Chicago Press, 11-55.

[29] Group of Thirty. (2013). Long-term Finance and Economic Growth. Group of Thirty, Washington DC.

[30] Guiso, L. and Jappelli,T. (2005). Awareness and stock market participation. Review of Finance, 9: 537-567.

[31] Guiso, L., Sapienza, P., and Zingales, L. (2004). The role of social capital in financial development. American Economic Review, 94: 526-556.

[32] Guiso, L., Sapienza, P., and Zingales, L. (2008). Trusting the stock market. Journal of Finance, 63: 2557-2600. 
[33] Hackethal, A., Haliassos, M., and Jappelli, T. (2012). Financial advisors: A case of babysitters? Journal of Banking and Finance, 36: 509-524.

[34] Hausmann, R. and Sturzenegger, F. (2007). The missing dark matter in the wealth of nations and its implications for global imbalances. Economic Policy, 22: 469-518.

[35] Hong, H., Kubik, J., and Stein, J. (2004). Social Interaction and Stock-Market Participation. Journal of Finance, 59:137-163.

[36] Hortaçsu, A. and Syverson, C. (2004). Product differentiation, search costs, and competition in the mutual fund industry: A case study of S\&P 500 index funds. Quarterly Journal of Economics, 119: 403-456.

[37] Hung, A., Clancy, N., Dominitz, J., Talley, E., Berrebi, C., and Suvankulov, F. (2008). Investor and industry perspectives on investment advisors and broker-dealers. Rand Corporation Technical Report.

[38] Inderst, R. and Ottaviani, M. (2009). Misselling through agents. American Economic Review, 99: 883-908.

[39] Inderst, R. and Ottaviani, M. (2012a). Competition through commissions and kickbacks. American Economic Review, 102: 780-809.

[40] Inderst, R. and Ottaviani, M. (2012b) Financial advice. Journal of Economic Literature, 50: 494-512

[41] Jensen, M. (1968). The performance of mutual funds in the period 1945-1964. Journal of Finance, 23: 389-416.

[42] Jordà, O., Schularick, M., and Taylor, A. (2015). Betting the house. Journal of International Economics, 96: 2-18.

[43] Kahneman, D. and Tversky, A. (1979). Prospect theory: An analsysis of choice under risk. Econometrica, 47: 263-291.

[44] Karlan, D. (2005). Using Experimental Economics to Measure Social Capital and Predict Financial Decisions. American Economic Review, 95: 1688-99.

[45] Karlan, D., Ratan, A., and Zinman, J. (2014). Savings by and for the Poor: A Research Review and Agenda. Review of Income and Wealth, 60: 36-78.

[46] Khorana, A., Servaes, H., and Tufano, P. (2008) Mutual Funds Fees Around the World. Review of Financial Studies, 22: 1279-1309.

[47] Lewis, D. (1969). Convention: A Philosophical Study, Oxford: Blackburn.

[48] Litan, R. (201) In Defense of Much, But Not All, Financial Innovation. Unpublished, Brookings Institution.

[49] Lusardi, A. and Mitchell, O. S. (2006). Financial Literacy and Planning: Implications for Retirement Well-Being. Pension Research Council WP 1. 
[50] Lusardi, A. and Mitchell, O. S. (2007). Baby boomer retirement security: The roles of planning, financial literacy and housing wealth. Journal of Monetary Economics, 54,: $205-224$.

[51] Massa, M. and Simonov, A. (2006). Hedging, familiarity and portfolio choice. Review of Financial Studies, 19: 633-685.

[52] Mehra R. and Prescott, E. (1985). The equity premium: A puzzle. Journal of Monetary Economics, 15: 145-161.

[53] Merton, R. C. (1969). Lifetime portfolio selection under uncertainty:The continuoustime case. Review of Economics and Statistics, 51: 247-257.

[54] Merton, R. C. (1971). Optimum consumption and portfolio rules in a continuous-time model. Journal of Economic Theory, 3: 373-413.

[55] OECD (2006). Infrastructure to 2030: Telecom, Land Transport, Water and Electricity. OECD, Paris.

[56] Ostry, J., Ghosh, R., Habermeier, K., Chamon, M., Qureshi, M., and Reinhardt, D. (2010). Capital Inflows: The Role of Controls. IMF Staff Position Note, 10/04

[57] Philippon, T. and Reshef, A. (2012). Wages and Human Capital in the U.S. Finance Industry: 1909-2006. Quarterly Journal of Economics, 127: 1551-1609.

[58] Reinhart, C. and Reinhart, V. (2015). Financial Crises, Development, and Growth: A Long-term Perspective. The World Bank Economic Review, 29: 1-24.

[59] Reinhart, C. and Rogoff, K. (2009). This Time Is Different. Eight Centuries of Financial Folly. Princeton, Princeton University Press.

[60] Reinhart, C. and Sbrancia, B. (2015). The liquidation of government debt. Economic Policy, 30: 291-333.

[61] Samuelson, W. and Zeckhauser, R. (1988) Status Quo Bias in Decision making. Journal of Risk and Uncertainty, 1: 7-59.

[62] Shackman, J. (2006) The equity premium and market integration: Evidence from international data. International Financial Markets, Institution and Money, 16: 155179 .

[63] Schechter, L. (2007). Traditional trust measurement and the risk confound: an experiment in rural Paraguay. Journal of Economic Behavior and Organization, 62: 272-292.

[64] Sunstein, C. and Thaler, R. (2008). Nudge: Improving Decisions about Health, Wealth, and Happiness. New Haven, Yale University Press.

[65] Swensen, D. (2005) Unconventional Success: A Fundamental Approach to Personal Investment. New York, Free Press. 
[66] Richard H. Thaler, R., Tversky, A. Kahneman, D., and Schwartz, A. (1997). The Effect of Myopia and Loss Aversion on Risk Taking: An Experimental Test. Quarterly Journal of Economics, 112: 647-661.

[67] Vissing-Jørgensen, A. (2003). Perspectives on behavioral finance: Does "irrationality" disappear with wealth? Evidence from expectations and actions. NBER Macroeconomics Annual.

[68] Williamson, J. (1990) What Washington Means by Policy Reform, in: Williamson, J. (ed.): Latin American Readjustment: How Much has Happened, Washington: Institute for International Economics.

[69] World Bank (2013a). Financial capability in low and middle-income countries: measurement and evaluation. The World Bank, Washington DC.

[70] World Bank (2013b). Financing for Development Post 2015. The World Bank, Washington DC. 